Int. J. Morphol.,

35(2):603-610, 2017

\title{
Protective Effect of Lepidium sativum Seed Extract on Histopathology and Morphology of Epididymis in Diabetic Rat Model
}

\author{
Efecto Protector de Extracto de Semilla Lepidium sativum Sobre la Histopatología \\ y Morfología del Epidídimo en Modelo de Rata Diabética
}

Mehran Kamani ${ }^{1}$; Elahe Seyed Hosseini ${ }^{1}$; Hamed Haddad Kashani ${ }^{1}$; Mohammad Ali Atlasi ${ }^{1}$ \& Hossein Nikzad ${ }^{1,2}$

KAMANI, M.; HOSSEINI, E. S.; KASHANI, H. H.; ATLASI, M. A. \& NIKZAD, H. Protective effect of Lepidium sativum seed extract on histopathology and morphology of epididymis in diabetic rat model. Int. J. Morphol., 35(2):603-610, 2017.

SUMMARY: Diabetes mellitus is a frequent and serious metabolic illness all over the world and plants have been a desirable source of medicine recently. Diabetes has unpleasant effect on male reproductive system and it may lead to male infertility. It causes erectile dysfunction and reduces ejaculate volume by affecting the health of small blood vessels and the small nerves that control ejaculation and also decreases libido by decreasing testosterone levels. Current study evaluated the possible protective efficiency of Lepidium sativum (Garden cress) seed extract on fasting blood sugar (FBS) and then assessed histopathological change of epididymis in streptozotocine (STZ)-induced diabetic rats. We randomly categorized 50 adult male Wistar rats into five groups (each 10 rats). Group 1 was control placebo group receiving only $0.1 \mathrm{ml}$ normal saline via gastric gavages, Group 2 as control diabetic rats received an intraperitoneal (IP) injection of STZ $60 \mathrm{mg} / \mathrm{kg}$ body weight. Rats with FBS >250 $\mathrm{mg} / \mathrm{dl}$ were considered as diabetic. Group 3 were diabetic rats receiving insulin in dose $3 \mathrm{U} / 100 \mathrm{~g}$ body weight and Groups 4 and 5 were diabetic rats that received $0.1 \mathrm{cc}$ of $200 \mathrm{and} 400 \mathrm{mg} / \mathrm{kg}$, ethanol extract of Lepidium sativum seed by gavages daily. One day after the last gavages, rats were anesthetized by chloroform. Epididymis duct was removed from abdomen and weighed with a digital scale. Afterwards, samples were putted in Bouin's solution for histological measurement. Administration of 200 and $400 \mathrm{mg} / \mathrm{ml}$ doses of Lepidium sativum seed extract increased epithelium height and decreased interstitial volume density and fibro muscular thickness significantly. Also, volume density of epithelium, fibro muscular, lumen and interstitial decreased significantly. Tubular and lumen diameter did not change significantly in different groups. It appears Lepidium sativum seed extract is a beneficial protective supplementary agent against adverse effects of diabetes on male reproductive system.

KEY WORDS: Diabetes; Epididymis; Lepidium sativum (garden cress); Streptozotocine; Insulin.

\section{INTRODUCTION}

Diabetes mellitus (DM) is one of the widespread metabolic disorders that has a significant adverse effects on vital organs such as heart, kidneys, eyes and peripheral nerves (Valko et al., 2005). Diabetes also has debasing effects on male sexual function such as impotency, reduced libido and sterility and these changes are due to reduced insulin secretion (Surai et al., 2006). Hyperglycemia in diabetes, impairs protein function and causes histopathological changes in the germinal gonads, such as the epididymis and the prostate. Streptozotocine (STZ) induction of diabetes in experimental models widely used to study glycemic and lipidemic changes in diabetic models (Agarwal et al., 2006).

The epididymis duct is a canal that transports, concentrates and stores the spermatozoa. It is also known that the spermatozoa leaving the testis are immobile, immature and unable to fertilize an oocyte but epididymis plays important role in maturing sperms (Flesch \& Gadella, 2000). The epididymis, an important organ of male reproduction system, secretes a specific fluid substances and its epithelium that serves a compatible environment for sperms to acquire motility and fertilizing potential (Gatti et al., 2004). In addition to sperm maturation, the epididymis plays a significant role in transport, concentration, protection and storage of spermatozoa (caudal part) (Bucak et al., 2010). In rats, the epididymal epithelium consists of several cell types, such as principal cells, basal cells, apical cells, narrow or flask cells and clear cells that are vulnerable to damages in diabetic disease (Cornwall, 2009). $\mathrm{Na}(+)-\mathrm{K}(+)$ ATPase, $\mathrm{Mg}^{2+}$ ATPase and $\mathrm{Ca}^{2+}$ ATPase are enzymes involved in sperm maturation located in the epididymis particularly in the epididymal tail (Schwarz et al., 2013). The enzymes activity in diabetic patient (Oberbach $e t$

\footnotetext{
${ }^{1}$ Anatomical Sciences Research Center, Kashan University of Medical Sciences, Kashan, Iran.

${ }^{2}$ Gametogenesis Research Center, Kashan University of Medical Sciences, Kashan, Iran.
} 
al., 2006), therefore it may induce erectile dysfunction which could be recovered by insulin treatment (Yamanaka et al., 2003).

A large amount of free radicals generated in diabetic patients and long-term exposure can cause the body damage (Sujatha \& Shalin, 2012). In diabetes due to increase of free radicals, antioxidant system is damaged and this may cause irreparable toll on the body (Martín-Gallán et al., 2003; Rolo $\&$ Palmeira, 2006). An imbalance between the production and elimination of reactive oxygen species (ROS), which is one of the most important free radicals, leads to injurious diabetes (Agarwal et al., 2005). There are different mechanisms to inhibit oxidative stress and reduce the harm caused by ROS. One of these mechanisms is antioxidant system that act as cleaner of free radicals and protects cells from ROS attacks. These mechanisms divide into two categories: enzymatic and non-enzymatic. A variety of nonenzymatic contains vitamins A and E, Carotenoids, Ubiquinone profiling and Ascorbic acid, uric acid, Taurine, Pyruvate, glutathione and coenzyme $Q$ and one of the main sources of them is medical herbs (Valko et al.; Surai et al.). Vitamin E has been identified as "vitamin of reproduction". Recent research has shown that vitamin $\mathrm{E}$ is located in spermatozoa and plays antioxidants role (Surai et al.).

Insulin is a hormone that is secreted from the pancreas islets and plays a key role in the body's metabolism and its dysfunction activity can cause diabetic disease. Nowadays insulin is used as a routine medicine for treatment of diabetes (Rossetti et al., 1987). Although insulin is one of the most widely used drugs in treatment of diabetes but defects such as ineffective use by mouth, lasting a short time and fatal hypoglycemia from increased doses can limit use of this drug, therefore researchers trying to find a suitable alternative to insulin from synthetic and plant resources (Mazloom et al., 2013).

Garden cress or GC (Lepidium sativum) from Brassicaceae family is an annual plant that grows up to $60 \mathrm{~cm}$ height. Seeds, leaves and roots of GC are commercially important because of useful pharmaceutical compounds and it is an important plant in traditional medicine and largely consumed in many countries (Pinheiro et al., 2011; Mohammad et al., 2012; Haddad-Kashani et al., 2012; Kashani et al., 2013). GC is used in the form vegetable in many parts of the world (Samson et al., 2012). Originated primarily of GC is Eritrea and Ethiopia and seeds of GC are brownish-red and oval shape (Datta et al., 2011). Seeds of $\mathrm{GC}$ is a rich natural source of flavonoids, coumarins, sulphur glycosides, triterpenes, sterols and various imidazole alkaloids (Eddouks et al., 2005). These compounds are known for many medical applications as bronchial asthma, hiccups, cough with expectoration, bleeding piles, hypertension and renal disease
(Paranjape \& Mehta, 2006). The active constituents of GC are Sulfur-containing compounds that in this plant called Diallyl Disulfide (Allicin) and glucosinolates (GLS) that are Cancer prevention materials (Mazloom et al., 2013). GC seeds contain of fatty acids and carotenoids. The most abundant fatty acids, respectively are; a-Linolenic acid (42.1\%), Oleic acid $(39.9 \%)$ and Linoleic acid $(11.8 \%)$ and it's carotenoids contains: Beta-carotene, Lutein and Zeaxanthin (Diwakar et al., 2010; Hosseyni et al., 2012).

Seeds of GC are known in many countries, in this regard, recent researches concentrated on the lowering effects of GC seeds on high blood sugar and fat. The inevitable role of the epididymis in sperm maturation is well established. However, there is a lack of information on the impact of diabetes, Garden Cress extract and Insulin on epididymis. Complications of diabetes imposes many difficulties on the patients an related society, therefore we decided to design and investigate the protective effect GC seeds extract on histopathological changes of epididymis in streptozotocininduced diabetic rats.

\section{MATERIAL AND METHOD}

Induction of Diabetes. After an overnight fasting, a single dose of $60 \mathrm{mg} / \mathrm{kg}$ body weight of streptozotocine (STZ, SigmaAldrich, USA) was injected intraperitoneally (IP). To prepare the solution $10 \mathrm{mg}$ of streptozotocine was dissolved in $0.1 \mathrm{ml}$ of $0.1 \mathrm{M}$ citrate buffer, $\mathrm{PH} 4.5$ according to the instruction. After 3 days of STZ treatment, blood glucose level was measured by an Easy glucometer (Beurer GL40, Hungary). Rats with polyuria and a blood sugar level more than $250 \mathrm{mg}$ / $\mathrm{dl}$ were considered as diabetic rat (Soudamani et al., 2005).

Garden cress (GC) extract. GC seeds were got from Barij Essence Company in Kashan, Iran. To prepare the alcoholic extract, $500 \mathrm{~g}$ of GC seeds was grinded and mixed completely in $96 \%$ ethanol for $24 \mathrm{~h}$. The mixture was filtered afterward ethanol was added for another 12 hours and filtered again. The resulting material was dried in ovens at $50{ }^{\circ} \mathrm{C}$. The dried extract was weighted and solution of 200 and $400 \mathrm{mg} / \mathrm{kg}$ in distilled water was prepared (Samson et al.).

Animal's experiments. In this study, fifty healthy adult male albino Wistar rats, weighing 280-320 g and eight weeks of age, were obtained from Kashan University of Medical Sciences, Kashan, Iran. During the experiments, they were maintained in a temperature controlled room with a $12 \mathrm{~h} / 12$ $\mathrm{h}$, light/dark schedule and provided with standard rat pellet diet and water. All the experiments were approved by the Animal Research Committee in our university. 
Experimental design. Fifty rats were randomly categorized into five groups of ten animals each. Group 1 was healthy animals receiving only $0.1 \mathrm{ml}$ of saline by stomach gavage to reflect the effect of gavage on the animals. Group 2 was diabetic rats with no further treatment. Group 3 was diabetic rats receiving daily subcutaneous injection of $3 \mathrm{U} / 100 \mathrm{~g}$ body weight insulin (Sigma-Aldrich, USA) divided into a morning (10AM, $2 \mathrm{U}$ ) and afternoon (4PM, $4 \mathrm{U}$ ) injection (Pinheiro et al.). Group 4 and 5 were diabetic rats receiving 200 and $400 \mathrm{mg} / \mathrm{kg}$ of GC extract by stomach gavage respectively for 28 days.

Sample collection. After four weeks and $24 \mathrm{~h}$ after the last dose of treatment, animals were weighed and anesthetized by chloroform. Blood samples were collected from the heart ventricle for measuring blood sugar level (FBS). Epididymis was carefully dissected out, cleaned from adhering fats and connective tissues, and weighed accurately on a digital balance. Epididymis was fixed in Bouin's fluid for histological examination. Tissue samples were processed (Shandon Eliot model) to prepare paraffin blocks. Histological sections $(5 \mathrm{~mm})$ were stained with Hematoxylin and Eosin(H\&E) (Kashani et al., 2013; Nikzad et al., 2013).

\section{Histological examination}

Morphometric studies. Microscopic sections of caudal epididymis looked at an Inverted Microscope (Nikon Inverted Microscope Eclipse Ti with DS camera control Unit Ds-L2). Microscope was equipped with a square lattice containing 121 intersections to determine volume density (Weibel \& Paumgartner, 1978). For each animal, five sections were chosen for the Morphometric studies.

Mean diameter. The mean diameter of the tubules and lumen of caudal epididymis were measured in 5 random tubules using an oculometer. The mean diameter of the tubule of caudal epididymis was measured using the formula (Mean diameter length+ breadth of the tubule/2).
The mean diameter of the lumens of caudal epididymis was measured with the formula (Mean diameter of lumen mean diameter of tubule $-(2 \mathrm{x}$ diameter of epithelium $)$

The epithelium height and fibromuscular thickness of tubules was determined by Nikon microscope

Volume density $(\mathbf{V v})$. A point-counting method was used to measure the volume density of the whole tubule, lumen, epithelium, and interstitial. The volume density was obtained by dividing the number of points on a tissue compartment (PN) on the total number of points (Ptn). Volume density determined in X100 with following formula (Romppanen $e t$ al., 1980): $\mathrm{V}_{\mathrm{v}}=\mathrm{PN} / \mathrm{Ptn}$

Ethical approval. All procedures performed in studies involving animal participants were in accordance with the ethical standards of the institutional and national research committee and with the 1964 Helsinki declaration and its later amendments.

Statistical analysis. Statistical analyses were carried out by ANOVA and post hoc test such as Tukey's HS and Dunnett's T3 test using SPSS 12 software, and a P-value of $\mathrm{p} \leq 0.05$ was considered as significant.

\section{RESULTS}

Histopathological findings. Histopathological changes such as decrease of epithelium height, density of epithelium, and increase of fibromuscular thickness and density of interstitial were detected in diabetic rats (Fig. 1). Table I shows a mean value for epithelium, fibromuscular layer thickness, diameter of the epididymal tubule and lumen and volume density of epithelium, fibromuscular, lumen and interstitial tissue in caudal epididymis. In the diabetic group epithelium thickness significantly decreased, fibromuscular layer thickness

Table I. Protective effect of Garden Cress extract seeds on histology of epididymis in the adult diabetic male rats with STZ

\begin{tabular}{|c|c|c|c|c|c|}
\hline Parameters & Control & Diabetic & Insulin & GC 200(mg/kg) & $\begin{array}{c}\text { GC } \\
400(\mathrm{mg} / \mathrm{kg})\end{array}$ \\
\hline Epithelium height $(\mu \mathrm{m})$ & $6.29 \pm 1.31$ & $4.00 \pm 1.30$ & $5.41 \pm 0.94 \mathrm{a},{ }^{\mathrm{b}}$ & $5.26 \pm 0.76^{\mathrm{a}, \mathrm{b}}$ & $5.3 \pm 0.66 \mathrm{a}^{\mathrm{b}}$ \\
\hline F ibromuscular thickness $(\mu \mathrm{m})$ & $0.99 \pm 0.21$ & $2.21 \pm 0.70$ & $1.27 \pm 0.40 \mathrm{a}^{\mathrm{b}}$ & $1.35 \pm 0.35^{\mathrm{b}}$ & $1.46 \pm 0.5^{3 b}$ \\
\hline Diameter of tubule $(\mu \mathrm{m})$ & $60.2 \pm 14.4$ & $66.2 \pm 9.4$ & $65.8_{ \pm 1} 3.3$ & $65.4_{ \pm 8.4}$ & $61.5 \pm 10.5$ \\
\hline Diameter of lumen $(\mu \mathrm{m})$ & $47.3 \pm{ }_{1}^{1} 6.1$ & $58.2 \pm 9_{9} .9$ & $55.00 \pm{ }_{1} 3.1$ & $54.9 \pm 9.0$ & $50.8 \pm 11.0$ \\
\hline Volume density of epithelium & $39 \pm{ }_{8}^{1} .0$ & $15.5 \pm_{3} .1$ & $33 \pm{ }_{6} \cdot 0 \mathrm{~b}$ & $30 \pm 7.0 \mathrm{~b}$ & $34 \pm 8.0^{\mathrm{b}}$ \\
\hline Volume density of Fibromuscular & $2.5 \pm{ }_{1} \cdot 6$ & $8.1 \pm 2.0$ & $2.5 \pm 1.7^{\mathrm{b}}$ & $3 \pm{ }_{1} .0$ & $4 \pm 2.0$ \\
\hline Volume density of lumen & $51 \pm_{9} .1$ & $66.6 \pm \pm_{8} .6$ & $58.8^{ \pm} \pm 6.9$ & $59 \pm{ }_{7} .0 \mathrm{~b}$ & $53 \pm 10.0 \mathrm{~b}$ \\
\hline Volume density of interstitial & $7.5 \pm{ }_{5} .0$ & $11.1 \pm_{4}^{\circ} \cdot 6$ & $6.3 \pm_{3} .3$ & $6.7 \pm 3.5 \mathrm{~b}$ & $7.2 \pm 4.4^{\mathrm{b}}$ \\
\hline
\end{tabular}

Values are expressed as mean \pm SD for ten rats in each group.

a: Significant differences as compared with the control group at $\mathrm{P}<0.05$

b: Significant differences as compared with the Diabetic group at $\mathrm{P}<0.05$ 

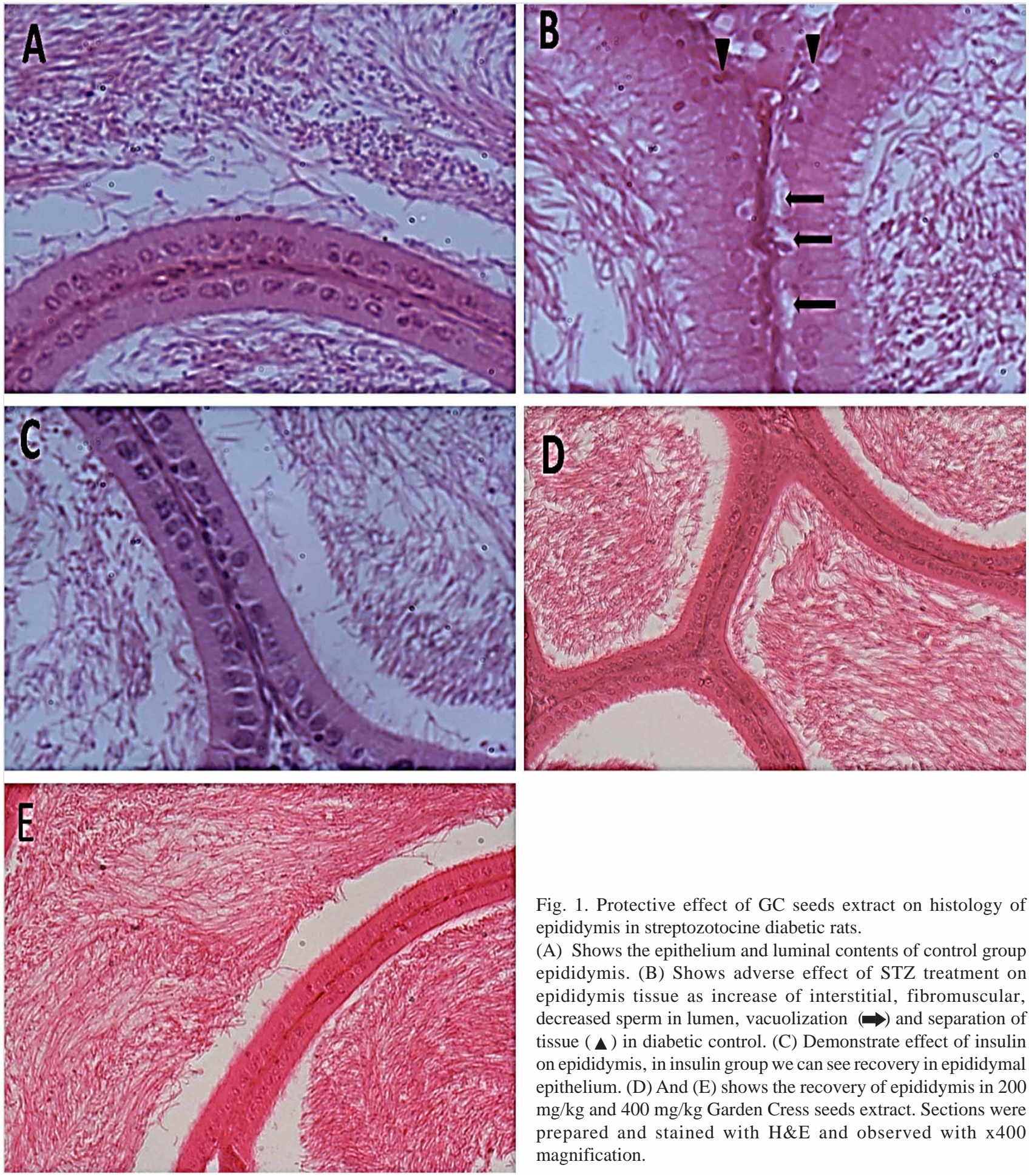

Fig. 1. Protective effect of GC seeds extract on histology of epididymis in streptozotocine diabetic rats.

(A) Shows the epithelium and luminal contents of control group epididymis. (B) Shows adverse effect of STZ treatment on epididymis tissue as increase of interstitial, fibromuscular, decreased sperm in lumen, vacuolization $(\Leftrightarrow)$ and separation of tissue ( $\boldsymbol{\Delta}$ ) in diabetic control. (C) Demonstrate effect of insulin on epididymis, in insulin group we can see recovery in epididymal epithelium. (D) And (E) shows the recovery of epididymis in 200 $\mathrm{mg} / \mathrm{kg}$ and $400 \mathrm{mg} / \mathrm{kg}$ Garden Cress seeds extract. Sections were prepared and stained with $\mathrm{H} \& \mathrm{E}$ and observed with $\mathrm{x} 400$ magnification.

significantly increased but these changes were improved significantly by Garden Cress seeds extract. In GC 200 and $400 \mathrm{mg} / \mathrm{kg}$, compared with diabetic group, epithelium height significantly increased also fibromuscular thickness decreased. Other changes in histopathological parameters are shown completely in Table I. 
Body and Epididymis weight. Table II compares the effects of STZ- induced diabetes, consuming the Garden Cress seed extract and Insulin replacement on body and epididymis weight of rats. Results show that the administration of Garden Cress 200 and $400 \mathrm{mg} / \mathrm{kg}$ preserved weight of body partially. Induction of diabetes with STZ significantly reduced the body weight.
Fasting Blood Sugar (FBS). In diabetic rats, FBS level was significantly increased, but Garden Cress seed extract in doses of 200 and $400 \mathrm{mg} / \mathrm{kg}$ decreased blood sugar significantly. Table II shows changes of FBS in different groups.

Table II. Protective effect of GC seed extract on body and epididymis weights and Fasting Blood Sugar (FBS) in the adult diabetic male rats with STZ

\begin{tabular}{|c|c|c|c|c|c|}
\hline Parameters groups & Control & Diabetic & Insulin & GC $200 \mathrm{mg} / \mathrm{kg}$ & GC400 m g/kg \\
\hline Body weight(g) & $280 \pm 1_{1} 9.40$ & $181_{ \pm 1} 8.33$ & $272 \pm 15^{41^{\circ}}$ & $190 \pm_{2} 1.30$ & $188_{ \pm 15^{80}}$ \\
\hline Epididymis weight(g) & $0.52 \pm 0.000$ & $0.373 \pm 0.063$ & $0.507 \pm 0.028 \mathrm{~b}$ & $0.427 \pm_{0} .070$ & $0.374 \pm 0.040$ \\
\hline $\mathrm{FBS}_{2}-\mathrm{FBS}_{1} *$ & $0.87_{ \pm 90}^{ \pm}$ & $1.3 \pm 5^{7}$ & $-126 \pm{ }_{1} 12^{\mathrm{a}, \mathrm{b}}$ & $-31.3 \pm 73.80^{\mathrm{a}, \mathrm{b}}$ & $-1.62 \pm 181.00$ \\
\hline
\end{tabular}

Values are expressed as mean $\pm \mathrm{SD}$ for ten rats in each group. a: Significant differences as compared with the control group at $\mathrm{P}<0.05 \mathrm{~b}$ : Significant differences as compared with the Diabetic group at $\mathrm{P}<0.05$. *FBS1 shows fasting blood sugar of rats in beginning of the experiment. *FBS2 shows fasting blood sugar of rats in the end of experiment. *FBS2-FBS1 demonstrates variation of the fasting blood sugar in the beginning and end of experiment

\section{DISCUSSION}

The purpose of current study was to examine the effect of alcoholic extract of 200 and $400 \mathrm{mgkg} \mathrm{GC}$ on histopathological changes of epididymis and blood glucose in STZ induced diabetic rats, also comparative effect of above results with application of insulin in diabetic rats. Our study demonstrated that adding 200 and $400 \mathrm{mg} / \mathrm{kg} \mathrm{GC}$ seed extract to diabetic rat diet could reduce blood glucose significantly and increase histology parameters particularly diameter of epithelium.

This increase might be due of several antioxidant factors, such as high amount flavonoids, coumarins, sulphur glycosides, triterpenes, sterols and various imidazole alkaloids (Eddouks et al.) and different groups of B, C, D, E vitamins that prevent tissue damages (Schultz \& Gmelin, 1952). Antioxidants are major factor to preserve tissue of epididymis from histopatological damages. Reactive oxygen species (ROS) produced in mitochondria is considered as by-products of normal oxidative metabolism (Raha \& Robinson, 2001).

Research has shown that vitamins of C, E, and B are useful to reduce the toxic effects of free radicals on genital gonads (Khaki et al., 2012). Naji et al. (2013) study on testicular and epididymal tissue showed that consumption of alcoholic extract of GC at dose of $96 \mathrm{mgkg}$ significantly increased sperm concentration in rabbits and improved histological efficacy of testes and epididymis which is related to existence of vitamin $\mathrm{E}$ in GC seeds.
Scientist reported that alcoholic-soluble compound that called Allicine in extract of GC seeds caused a significant increase in blood insulin levels and liver glycogen in diabetic rats treated by Alloxan (Shukia et al., 2000).

Our results indicated reduction of glucose level after feeding of GC seeds extract due to presence of alkaloids, flavonoids, cysteine and glycine. Another study also demonstrated administration of $20 \mathrm{mg} k \mathrm{~kg}$ GC seeds extract significantly decreased blood sugar (30\%), cholesterol (22 $\%)$, triglycerides $(25 \%)$ and LDL (23\%) in diabetic rats due to antioxidant compounds of GC seeds (Amawi \& Aljamal, 2012). Consumption of $200 \mathrm{mg} / \mathrm{ml}$ of alcoholic extract increased the weight of epididymis. This may be defined by the fact that seeds of GC have disulfide in their composition which is similar to Insulin's disulfide bond (Tocmo et al., 2015).

One interesting finding was that the consumption of $400 \mathrm{mg} k \mathrm{~kg}$ Gecreased the weight of epididymis while increasing body weight and may have similar effect on other cells. This may be defined by the fact that GC in hyper dose, has reverse affection on genital gonads (Meikle et al., 1996).

Meikle et al. studied inhabitation of Oleic acid on cholesteryl esterase that is essential for the synthesis of testosterone in the Leydig cells. Their results showed that Oleic acid in high concentrations reduced the production of testosterone significantly in response to $\mathrm{LH}$, the concentration 
of cholesterol in the Leydig cells and cholesterol esterase activity in the cytosol and mitochondria. There is a good possibility that the usage of essential fatty acids in high concentrations can have the reverse effect on genital gonads (Meikle et al.).

Other scientist studied cytotoxic effect of aqueous extract of GC seeds on human breast cancer cells. They applied serum-free media (SFM) that contains one of several concentration of the extract $(1: 1),(1: 10),(1: 100),(1: 1000)$ or $(1: 10000)$ and showed ability of GC seeds to inhibit growth of cancer cells significantly (Mahassni \& Al-Reemi, 2013).

Insulin treatment of diabetic rats caused significant increase of body and epididymis weight and imposed histological effects on epithelium diameter and volume density of epithelium. The findings support Bahey's study et al. (2014) that showed treatment of diabetes rats with insulin, restore histoartichect anterior lobe of prostate, increase the epithelial height and raise the number of mast cells (Bahey et al., 2014).

Previous study demonstrated that usage of combined insulin and steroid hormones partially revived hormonal and angiogenic imbalance created by DM (Fávaro \& Cagnon, 2010). The effect of insulin on function of fetuses prostate in maternal diabetic rats has been investigated. The findings showed that insulin injection in maternal diabetic rats recovered histology and secretion condition of prostate in neonate rat (Santos et al., 2014).

Our results showed that diabetic disease in rats had positive correlation with decrease body and epididymis weight. Consuming GC 200 and 400 mg/kg and insulinpreserved body weight significantly. Increased blood glucose in diabetic rats created vacuoles and shrinkage in basal membrane (Kaczmar, 1998). In diabetic rats, epididymal lumen is almost devoid of sperm. This is due to releasing free radicals in diabetic rats (Yuan \& Bieber, 2003). Physiologic cell death is a major factor to increase fibromuscular and interstitial tissue in diabetic rats. Herbal antioxidant is involved in suppression of cell death by modulating of free radicals (Wood \& Youle, 1994).

In a healthy body, ROS and antioxidant are in balance, but in diabetic patients with oxidative disorder the balance is disrupted, which leads to increase of ROS production that causes cell damage and oxidative stress (Agarwal et al., 2008). Activity alteration of pancreatic antioxidant enzymes and increased oxidative stress demonstrated by Ravi et al. (2004). Several toxic effects of DM on epididymis and testis have been related to oxidative stress and radical production that are in agreement with our finding (Navarro-Casado et al., 2010). Consumption of GC 200 and $400 \mathrm{mg} / \mathrm{kg}$ could protect epididymis from vacuolization, shrinkage and separation of epithelium as side-effects of DM. Our finding is in agreement with the effect of dietary supplementation of GC seeds on liver histopathology in rats fed high cholesterol diet showed that the administration of $6 \mathrm{~g} / \mathrm{kg}$ GC seeds could restore histopathology of liver as: vacuolization, fatty changes, fatty cyst and lobular disarray (Althnaian, 2014).

In our study the administration of GC extract 200 and $400 \mathrm{mg} / \mathrm{kg}$ in diabetic rats was able to recover the histology parameters of epididymis that might be related to the GC seed antioxidant compounds. We believe in the current study investigation of biochemical factors like as $\mathrm{HbA}_{1} \mathrm{c}$, total antioxidant capacity (TAC) and reactive oxygen species (ROS) could help to accomplish easier studies. Therefore, we are going to design a new study that examines different groups of rats at different times (1, 2, 3, 4, 5 and 6 weeks) and determine biochemical parameter of the study.

\section{CONCLUSIONS}

Our findings indicated that $200 \mathrm{mg} / \mathrm{kg}$ of GC seed extract could recover the STZ-induced side effects in epididymis histology parameters through preventing oxidative stress. Even though the results deduced in rats should be followed by a human trial study but based on this study it could be suggested the $200 \mathrm{mg} \mathrm{kg}$ of GC seed extract added to insulin treatment can have potential protective effect in DM. In the current study for optimizing of the best therapeutic doses we applied different amount of GC (50 mg/ $\mathrm{kg}$ up to $500 \mathrm{mg} / \mathrm{kg}$ ), and the pilot studies leads us to the amount of 200 and 400 $\mathrm{mg} / \mathrm{kg}$. Doses Lower than $200 \mathrm{mg} / \mathrm{kg}$ dose did not show significant effect and doses higher than $400 \mathrm{mg} / \mathrm{kg}$ showed toxicity effect.

The results of this study emphasizes the use of 200 $\mathrm{mg} / \mathrm{kg}$ of GC seed extract as a powerful source of antioxidant supplementary food in diabetic men. Also these results suggest further studies to prevent $200 \mathrm{mg} / \mathrm{kg}$ of GC seed extract as a drug to protect patients from the side effects of diabetic disease.

\section{ACKNOWLEDGEMENTS}

This study was financially supported by the deputy of research in Kashan University of Medical Science and Kashan Anatomical Science Research Center (Grant No. 9047). The authors gratefully acknowledge the kind cooperation of all staff in the Anatomical Science Research Center, Kashan University of Medical Science. 
KAMANI, M.; HOSSEINI, E. S.; KASHANI, H. H.; ATLASI, M. A. \& NIKZAD, H. Efecto protector de extracto de semilla Lepidium sativum sobre la histopatología y morfología del epidídimo en modelo de rata diabética. Int. J. Morphol., 35(2):603-610, 2017.

RESUMEN: La diabetes mellitus es una enfermedad metabólica frecuente y grave que afecta a los hombres en todo el mundo. Recientemente, las plantas han sido una fuente deseable de medicina para este tipo de enfermedad. La diabetes tiene un efecto perjudicial en el sistema reproductivo masculino y puede conducir a la infertilidad. Causa disfunción eréctil y reduce el volumen de la eyaculación al afectar los pequeños vasos sanguíneos y los nervios que controlan la eyaculación. También disminuye la libido reduciendo los niveles de testosterona. El presente estudio evaluó la posible eficacia protectora del extracto de semilla de Lepidium sativum en la glucemia en ayunas y también se evaluó el cambio histopatológico del epidídimo en ratas diabéticas inducidas por estreptozotocina (STZ). Se dividieron aleatoriamente 50 ratas Wistar macho adultas en cinco grupos de 10 ratas cada uno. El grupo 1 recibió 0,1 ml de solución salina normal a través de los gavajes gástricos, el grupo 2 de ratas diabéticas control recibió una inyección intraperitoneal (IP) de STZ 60 mg / $\mathrm{kg}$ de peso corporal. Las ratas con FBS> $250 \mathrm{mg} / \mathrm{dl}$ se consideraron como diabéticas. El Grupo 3 eran ratas diabéticas que recibieron insulina en dosis de $3 \mathrm{U} / 100 \mathrm{~g}$ de peso corporal y los Grupos 4 y 5 estaban compuestos por ratas diabéticas que recibieron 0,1 cc con 200 y $400 \mathrm{mg} / \mathrm{kg}$, de extracto de etanol de semillas de Lepidium sativum por gavajes diarios. Un día después de los últimos gavages, las ratas fueron anestesiadas con cloroformo. Se extrajo el epidídimo y se pesó con una pesa digital. Posteriormente, las muestras se pusieron en solución de Bouin para el estudio histológico. La administración de dosis de 200 y $400 \mathrm{mg} / \mathrm{ml}$ de extracto de semilla Lepidium sativum aumentó la altura del epitelio y disminuyó significativamente la densidad volumétrica intersticial y el grosor fibromuscular. Además, la densidad volumétrica del epitelio fibromuscular, lumen e intersticio disminuyeron significativamente. El diámetro tubular y el lumen no cambiaron significativamente en los diferentes grupos. El extracto de semilla de Lepidium sativum es un agente complementario beneficioso protector contra los efectos adversos de la diabetes en el sistema reproductor masculino.

\section{PALABRAS CLAVE: Diabetes; Epidídimo; Lepidium sativum (berro de jardín); Estreptozotocina; Insulina.}

\section{REFERENCES}

Agarwal, A.; Gupta, S. \& Sharma, R. K. Role of oxidative stress in female reproduction. Reprod. Biol. Endocrinol., 3:28, 2005.

Agarwal, A.; Gupta, S. \& Sikka, S. The role of free radicals and antioxidants in reproduction. Curr. Opin. Obstet. Gynecol., 18(3):32532, 2006.

Agarwal, A.; Makker, K. \& Sharma, R. Clinical relevance of oxidative stress in male factor infertility: an update. Am. J. Reprod. Immunol., 59(1):2-11, 2008

Althnaian, T. Influence of dietary supplementation of Garden cress (Lepidium sativum L.) on liver histopathology and serum biochemistry in rats fed high cholesterol diet. J. Adv. Vet. Anim. Res., 1(4):216-23, 2014.

Amawi, K. \& Aljamal, A. Effect of Lepidium sativum on lipid profiles and blood glucose in rats. J. Phys. Pharm. Adv., 2(8):277-81, 2012.

Bahey, N. G.; Soliman, G. M.; El-Deeb, T. A. \& El-Drieny, E. A. Influence of insulin and testosterone on diabetic rat ventral prostate: Histological, morphometric and immunohistochemical study. J. Microsc. Ultrastruct., 2(3):151-60, 2014.

Bucak, M. N.; Tuncer, P. B.; Sarıözkan, S.; Baspınar, N.; Taspınar, M.; Coyan, K.; Bilgili, A.; Akalın, P. P.; Büyükleblebici, S.; Aydos, S.; Ilgaz, S.; Sunguroglu, A. \& Oztuna, D. Effects of antioxidants on post-thawed bovine sperm and oxidative stress parameters: antioxidants protect DNA integrity against cryodamage. Cryobiology, 61(3):248-53, 2010.

Cornwall, G. A. New insights into epididymal biology and function. Hum. Reprod. Update, 15(2):213-27, 2009.

Datta, P. K.; Diwakar, B. T.; Viswanatha, S.; Murthy, K. N. \& Naidu, K. A. Safety evaluation studies on Garden cress (Lepidium sativum L.) seeds in Wistar rats. Int. J. Appl. Res. Nat. Prod., 4(1):37-42, 2011.

Diwakar, B. T.; Dutta, P. K.; Lokesh, B. \& Naidu, A. Physicochemical properties of garden cress (Lepidium sativum L.) seed oil. J. Am. Oil Chem. Soc., 87(5):539-48, 2010.

Eddouks, M.; Maghrani, M.; Zeggwagh, N. A. \& Michel, J. B. Study of the hypoglycaemic activity of Lepidium sativum L. aqueous extract in normal and diabetic rats. J. Ethnopharmacol., 97(2):391-5, 2005.
Fávaro, W. J. \& Cagnon, V. H. Effect of combined hormonal and insulin therapy on the steroid hormone receptors and growth factors signalling in diabetic mice prostate. Int. J. Exp. Pathol., 91(6):537-45, 2010.

Flesch, F. M. \& Gadella, B. M. Dynamics of the mammalian sperm plasma membrane in the process of fertilization. Biochim. Biophys. Acta, 1469(3):197-235, 2000.

Gatti, J. L.; Castella, S.; Dacheux, F.; Ecroyd, H.; Métayer, S.; Thimon, V. \& Dacheux, J. L. Post-testicular sperm environment and fertility. Anim. Reprod. Sci., 82-3:321-39, 2004.

Haddad-Kashani, H.; Seyed-Hoseini, E.; Nikzad, H. \& Aarabi, M. H. Pharmacological properties of medicinal herbs by focus on secondary metabolites. Life Sci. J., 9(1):509-20, 2012.

Hosseyni, E. S.; Kashani, H. H. \& Asadi, M. H. Mode of action of medicinal plants on diabetic disorders. Life Sci. J., 9(4):2776-83, 2012.

Kaczmar, T. Herbal support for diabetes management. Clin. Nutr Insights, 6(8):1-4, 1998.

Kashani, H. H., Moshkdanian, G.; Atlasi, M. A.; Taherian, A. A.; Naderian, H. \& Nikzad, H. Expression of galectin-3 as a testis inflammatory marker in vasectomised mice. Cell J., 15(1):11-8, 2013.

Khaki, A.; Farnam, A.; Badie, A. D. \& Nikniaz, H. Treatment Effects of Onion (Allium cepa) and Ginger (Zingiber officinale) on Sexual Behavior of Rat after Inducing an Antiepileptic Drug (lamotrigine). Balkan Med. J., 29(3):236-42, 2012.

Mahassni, S. \& Al-Reemi, R. M. Cytotoxic effect of an aqueous extract of Lepidium sativum L. seeds on human breast cancer cells. Indian J. Tradit. Knowl., 12(4):605-14, 2013.

Martín-Gallán, P.; Carrascosa, A.; Gussinyé, M. \& Domínguez, C. Biomarkers of diabetes-associated oxidative stress and antioxidant status in young diabetic patients with or without subclinical complications. Free Radic. Biol. Med., 34(12):1563-74, 2003.

Mazloom, Z.; Yousefinejad, A. \& Dabbaghmanesh, M. H. Effect of probiotics on lipid profile, glycemic control, insulin action, oxidative stress, and inflammatory markers in patients with type 2 diabetes: a clinical trial. Iran. J. Med. Sci., 38(1):38-43, 2013. 
Meikle, A. W.; Cardoso de Sousa, J. C.; Hanzalova, J. \& Murray, D. K. Oleic acid inhibits cholesteryl esterase and cholesterol utilization for testosterone synthesis in mouse Leydig cells. Metabolism, 45(3):293$9,1996$.

Mohammad, S. M.; Kashani, H. H. \& Azarbad, Z. Capparis spinosa L. Propagation and medicinal uses. Life Sci. J., 9(4):684-6, 2012.

Naji, N. S. \& Shumran, F. M. The effects of tocopherol extraction from Lepidium sativum seeds on the histology of testis, epididymis, and seminal vesicles of adult male rabbits. J. Biol. Agric. Healthc., 3(6):97100, 2013.

Navarro-Casado, L.; Juncos-Tobarra, M. A.; Cháfer-Rudilla, M.; de Onzoño, L. Í.; Blázquez-Cabrera, J. A. \& Miralles-García, J. M. Effect of experimental diabetes and STZ on male fertility capacity. Study in rats. J. Androl., 31(6):584-92, 2010.

Nikzad, H.; Kashani, H. H.; Kabir-Salmani, M.; Akimoto, Y. \& Iwashita, M. Expression of galectin-8 on human endometrium: Molecular and cellular aspects. Iran. J. Reprod. Med., 11(1):65-70, 2013.

Oberbach, A.; Bossenz, Y.; Lehmann, S.; Niebauer, J.; Adams, V.; Paschke, R.; Schön, M. R.; Blüher, M. \& Punkt, K. Altered fiber distribution and fiber-specific glycolytic and oxidative enzyme activity in skeletal muscle of patients with type 2 diabetes. Diabetes Care, 29(4):895900, 2006.

Paranjape, A. N. \& Mehta, A. A. A study on clinical efficacy of Lepidium sativum seeds in treatment of bronchial asthma. Iran. J. Pharmacol. Ther., 5(1):55-9, 2006.

Pinheiro, L. S.; de Melo, A. D.; Andreazzi, A. E.; Caires Junior, L. C.; Costa, M. \& Garcia, R. M. G. Protocol of insulin therapy for streptozotocin-diabetic rats based on a study of food ingestion and glycemic variation. Scand. J. Lab. Anim. Sci., 38(2):117-27, 2011.

Raha, S. \& Robinson, B. H. Mitochondria, oxygen free radicals, and apoptosis. Am. J. Med. Genet., 106(1):62-70, 2001

Ravi, K.; Ramachandran, B. \& Subramanian, S. Effect of Eugenia Jambolana seed kernel on antioxidant defense system in streptozotocininduced diabetes in rats. Life Sci., 75(22):2717-31, 2004.

Rolo, A. P. \& Palmeira, C. M. Diabetes and mitochondrial function: role of hyperglycemia and oxidative stress. Toxicol. Appl. Pharmacol., 212(2):167-78, 2006

Romppanen, T.; Huttunen, E. \& Helminen, H. J. An improved light microscopical histoquantitative method for the stereological analysis of the rat ventral prostate lobe. Invest. Urol., 18(1):59-65, 1980.

Rossetti, L.; Smith, D.; Shulman, G. I.; Papachristou, D. \& DeFronzo, R. A. Correction of hyperglycemia with phlorizin normalizes tissue sensitivity to insulin in diabetic rats. J. Clin. Invest., 79(5):1510-5, 1987.

Samson, E. S.; Olasunkanmi, A. K.; Joel, J. S. \& Alfred, E. F. Haematological and hepatotoxic potential of onion (Allium cepa) and garlic (Allium sativum) extracts in rats. Eur. J. Med. Plants, 2(3):290307, 2012.

Santos, S. A.; Rinaldi, J. C.; Martins, A. E.; Camargo, A. C.; Leonelli, C.; Delella, F. K.; Felisbino, S. L. \& Justulin, L. A. Jr. Impact of gestational diabetes and lactational insulin replacement on structure and secretory function of offspring rat ventral prostate. Gen. Comp. Endocrinol., 206:60-71, 2014.

Schultz, O. E. \& Gmelin, R. Purification of glycoside from Lepidum sativum by chromatography on a cellulose powder column. Arzneimittelforschung, 2(12):568-9, 1952.

Schwarz, A.; Wennemuth, G.; Post, H.; Brandenburger, T.; Aumüller, G. $\&$ Wilhelm, B. Vesicular transfer of membrane components to bovine epididymal spermatozoa. Cell Tissue Res., 353(3):549-61, 2013.

Shukia, R.; Sharma, S. B.; Puri, D.; Prabhu, K. M. \& Murthy, P. S. Medicinal plants for treatment of diabetes mellitus. Indian J. Clin. Biochem., 15(Suppl. 1):169-77, 2000.

Soudamani, S.; Malini, T. \& Balasubramanian, K. Effects of streptozotocin-diabetes and insulin replacement on the epididymis of prepubertal rats: histological and histomorphometric studies. Endocr. Res., 31(2):81-98, 2005.
Sujatha, S. \& J Shalin, J. J. Complementary therapeutic potential: A focus on polyherbal products for hyperglycemia. Asian J. Sci. Res., 5(1):113, 2012.

Surai, P. F.; Sparks, N. H. C. \& Speake, B. K. The role of antioxidants in reproduction and fertility of poultry. Conference. Verona, World Poultry Science Association (WPSA) - XII European Poultry Conference, 2006.

Tocmo, R.; Liang, D.; Lin, Y. \& Huang, D. Chemical and biochemical mechanisms underlying the cardioprotective roles of dietary organopolysulfides. Front. Nutr., 2:1, 2015.

Valko, M.; Morris, H. \& Cronin, M. T. Metals, toxicity and oxidative stress. Curr. Med. Chem., 12(10):1161-208, 2005.

Weibel, E. R. \& Paumgartner, D. Integrated stereological and biochemical studies on hepatocytic membranes. II. Correction of section thickness effect on volume and surface density estimates. J. Cell Biol., 77(2):584-97, 1978

Wood, K. A. \& Youle, R. J. Apoptosis and free radicals. Ann. N. Y. Acad. Sci., 738:400-7, 1994.

Yamanaka, M.; Shirai, M.; Shiina, H.; Tanaka, Y.; Tsujimura, A.; Matsumiya, K.; Okuyama, A. \& Dahiya, R. Diabetes induced erectile dysfunction and apoptosis in penile crura are recovered by insulin treatment in rats. J. Urol., 170(1):291-7, 2003.

Yuan, C. S. \& Bieber, E. J. Textbook of Complementary and Alternative Medicine. New York, The Partenon Publishing Group, CRC Press, 2003.

\author{
Corresponding author: \\ Hossein Nikzad \\ Anatomical Sciences Research Center \\ Kashan University of Medical Sciences \\ Kashan \\ IRAN
}

E-mail: nikzad@kaums.ac.ir

Received: $31-12-2016$

Accepted: 21-03-2017 